\title{
RESPON SETEK CABANG BAMBU KUNING (Bambusa vulgaris) TERHADAP PEMBERIAN AIA
}

\section{(THE RESPONSE OF BRANCH CUTTINGS YELLOW BAMBOO (Bambusa Vulgaris) BY GIVING INDOLE ACETIC ACID)}

\author{
Yosepin K. Simangunsong, Indriyanto, dan Afif Bintoro \\ Jurusan Kehutanan Fakultas Pertanian Universitas Lampung \\ Jl. Soemantri Brojonegoro No. 1 Bandar Lampung, 35145 \\ Email : simangunsong_yosepin@yahoo.com
}

\begin{abstract}
ABSTRAK
Bambu kuning merupakan salah satu spesies bambu yang dapat digunakan untuk bahan industri dan peralatan rumah tangga, karena kulit batangnya yang tebal, seratnya yang panjang, dan bentuknya yang indah. Keberhasilan tumbuh setek cabang bambu kuning masih rendah, hal ini merupakan salah satu permasalahan dalam pembibitan bambu. Untuk meningkatkan keberhasilan tumbuh setek cabang bambu kuning perlu digunakan zat pengatur tumbuh (ZPT). Oleh karena itu, penelitian ini dilakukan dengan memberikan asam indol asetat (AIA) pada setek cabang bambu kuning. Tujuan dari penelitian ini untuk mengetahui pertumbuhan setek cabang bambu kuning akibat pemberian asam indol asetat (AIA), dan mengetahui konsentrasi asam indol asetat (AIA) yang pengaruhnya paling baik terhadap pertumbuhan setek cabang bambu kuning. Penelitian ini dirancang menggunakan rancangan acak lengkap (RAL) dengan lima perlakuan, lima unit percobaan, dan tiap unit percobaan terdiri atas lima setek cabang. Perlakuan konsentrasi asam indol asetat meliputi 0 ppm, 100 ppm , $200 \mathrm{ppm}, 300 \mathrm{ppm}$, dan $400 \mathrm{ppm}$. Untuk menguji homogenitas ragam dilakukan dengan Uji Bartlett, data akan diuji dengan analisis ragam kemudian di uji lanjut dengan beda nyata jujur. Pertumbuhan setek cabang bambu kuning dengan parameter persentase hidup, jumlah tunas, panjang tunas, diameter tunas, dan jumlah daun diketahui signifikan, sedangkan untuk parameter panjang akar tidak signifikan.
\end{abstract}

Kata kunci: asam indol asetat, bambu kuning, setek cabang

\section{ABSTRACT}

Yellow bamboo is one of the bamboo species which used for industrial and house-hold materials, because it has a thick trunk outer layer, length of fiber, and beautiful shape. The success of cuttings grown yellow bamboo branch was lack. To increase the success of the yellow bamboo branches grow cuttings used growth regulators. Therefore, the research was conducted by giving indole acetic acid on yellow bamboo branch cuttings. The objective of this research was to known the growth of yellow bamboo branch cuttings by giving indole acetic acid and known the concentration of the indole acetic acid were the best influence on the growth of yellow bamboo branch cuttings. The research was designed with complete randomized design (CRD) with five treatment, five experimental units, and five branch cuttings for each experimental unit. The concentration of indole acetic acid (IAA) was 0 ppm, $100 \mathrm{ppm}, 200 \mathrm{ppm}, 300 \mathrm{ppm}$, and $400 \mathrm{ppm}$. To test the homogeneity range done with Bartlett test, the data will be tested by analysis of variance and then further tested with honestly significant difference test. Yellow bamboo branch cuttings growth by percentage of life parameters, number of shoots, shoot length, shoot diameter, and a significant number of leaves is known, whereas for root length parameter is not significant.

Key words : branch cutting, indole acetic acid, yellow bamboo 


\section{PENDAHULUAN}

Bambu merupakan hasil hutan bukan kayu yang telah lama dimanfaatkan oleh masyarakat. Tanaman bambu dapat tumbuh di daerah iklim basah sampai kering. Bambu dapat dimanfaatkan oleh manusia dari akar sampai daun (Kehutanan dan Perkebunan, 1999). Bambu kuning merupakan salah satu spesies bambu yang banyak digunakan untuk bahan baku industri dan rumah tangga karena kulit batangnya tebal, seratnya yang panjang, dan bentuknya yang indah.

Untuk memenuhi ketersediaan bambu kuning secara berkelanjutan perlu dilakukan perbanyakan bambu dengan cara generatif dan vegetatif. Perbanyakan bambu secara generatif memerlukan waktu lama terutama dalam pengadaan benih. Selain itu bambu jarang berbunga, berbuah, dan berbiji. Perlu diketahui bahwa tanaman bambu yang sedang berbunga hingga buah dan bijinya masak fisiologis memerlukan waktu 6--7 bulan. Oleh karena itu, perbanyakan tanaman bambu dengan generatif jarang dilakukan.

Adapun perbanyakan bambu secara vegetatif dapat dilakukan antara lain dengan setek cabang, setek batang, dan setek rhizoma. Perbanyakan dengan setek rhizoma seringkali merusak rumpun bambu, selain itu jumlah bibit yang diperoleh relatif sedikit. Setek batang berupa potongan dari berbagai pangkal batang yang masih segar dan yang mempunyai mata tunas, juga bisa digunakan untuk perbanyakan bambu, akan tetapi perbanyakan dengan cara ini kurang efektif karena memerlukan waktu yang cukup lama. Setek cabang berupa organ tanaman yang tumbuh di bagian pangkal batang yang merupakan sisa dari bahan perbanyakan dengan setek batang. Perbanyakan tanaman bambu dengan menggunakan setek cabang lebih efektif karena tidak merusak rumpun bambu, pembentukan rumpun lebih cepat, pengerjaannya mudah, tidak membutuhkan waktu yang lama, bahan setek dapat diperoleh dengan mudah dan dengan jumlah yang banyak (Departemen Kehutanan dan Perkebunan, 1999).

AIA merupakan salah satu jenis zat pengatur tumbuh yang fungsi utamanya untuk memacu pembentukan akar. Zat pengatur tumbuh (ZPT) adalah senyawa organik komplek alami yang disintesis oleh tanaman tingkat tinggi, yang berpengaruh pada pertumbuhan dan perkembangan tanaman. Pemberian ZPT akan efisien bila pemakaian ZPT pada konsentrasi yang tepat sesuai kebutuhan tanaman yang diteliti. Oleh karena itu, penelitian ini dilakukan menggunakan AIA dengan konsentrasi yang berbeda-beda yang diaplikasikan pada pangkal bahan setek cabang. Atas pertimbangan tersebut, dilakukan penelitian tentang pengaruh pemberian AIA terhadap pertumbuhan setek cabang bambu kuning, serta untuk mengetahui konsentrasi AIA yang paling baik terhadap pertumbuhan setek cabang bambu kuning.

\section{METODE PENELITIAN}

Penelitian ini dilaksanakan di Kebun Koleksi Lembaga Penelitian dan Pengembangan Hutan Palembang di Tanjung Agung, Kecamatan Tanjungan Kabupaten Lampung Selatan. Waktu penelitian dimulai pada bulan Maret sampai dengan bulan Juni 2012.

Bahan yang digunakan dalam penelitian ini adalah cabang bambu kuning sebanyak 125 cabang, AIA dengan konsentrasi 0 ppm, 100 ppm, 200 ppm, 300 ppm, dan 400 ppm, tanah lapisan atas, aquades, Furadan 3G, Dithane, $\mathrm{NaOH}$ dan air. Sedangkan alat yang digunakan dalam penelitian ini adalah polybag ukuran $15 \mathrm{~cm} \times 25 \mathrm{~cm}$, gelas ukur, alat timbangan, cangkul, ember, ayakan dari bambu, golok, gunting setek, gembor, lux meter, termohigrometer, pita meter, kaliper, pengaris ukuran $30 \mathrm{~cm}$, dan alat tulis.

Adapun persiapan dalam penelitian ini adalah dengan menggunakan media penumbuh setek berupa tanah lapisan atas. Tanah terlebih dahulu dipersiapkan seminggu sebelum bahan tanaman dipersiapkan. Tanah diayak, sehingga tanah yang dipergunakan sudah halus lalu 
diaksenisasi menggunakan Furadan 3G sebanyak 1 sendok makan dan Dithane sebanyak 3/4 sendok makan lalu diaduk rata. Setelah proses aksenisasi, tanah dibiarkan selama satu minggu. Tanah dimasukkan dalam polybag berukuran $15 \mathrm{~cm}$ x $25 \mathrm{~cm}$. Bahan setek diambil dari cabang jenis bambu kuning yang telah berumur 2--3 tahun. Setelah semua cabang yang dijadikan bahan setek terpilih, lalu dilakukan perendaman dengan AIA sesuai konsentrasi yang sudah ditentukan. Perendaman pangkal bahan setek dilakukan selama 15 menit.

Setelah perendaman, semua setek cabang yang sudah diberi perlakuan dimasukkan ke dalam polybag dengan posisi vertikal, ditata pada tempat yang sudah diberi naungan yang disiapkan seminggu sebelumnya dan sesuai dengan tata letak yang sudah ditentukan. Naungan yang dipergunakan dalam penelitian ini berupa daun bambu, yang bertujuan untuk mengurangi intensitas cahaya matahari terhadap tanaman. Penyiraman dilakukan satu kali sehari yaitu pagi atau sore hari, tetapi jika pada hari itu hujan maka penyiraman tidak perlu dilakukan. Penyiraman dilakukan dengan tujuan untuk memenuhi kebutuhan air pada tanaman. Penyiangan terhadap gulma dilakukan dengan cara mencabut gulma agar tempat di sekitar setek bersih dan setek dapat tumbuh dengan baik.

Rancangan percobaan yang digunakan dalam penelitian ini adalah Rancangan Acak Lengkap. Pada penelitian ini terdiri atas lima perlakuan yaitu setek bambu kuning dengan menggunakan AIA berkonsentrasi 0 ppm, 100 ppm, 200 ppm, 300 ppm, dan 400 ppm. Penelitian dilakukan dengan lima ulangan pada masing-masing perlakuan. Dalam satu unit percobaan terdiri atas lima setek cabang. Jadi, jumlah bahan tanaman (bahan setek) yang diperlukan sebanyak $5 \times 5 \times 5=125$ buah.

Variabel-variabel penelitian yang diamati adalah persentase hidup setek cabang yang dihitung pada akhir penelitian, panjang tunas dan jumlah tunas yang diukur setiap satu minggu sekali, jumlah daun, diameter tunas yang diukur pada akhir penelitian, dan panjang akar yang diukur pada akhir penelitian diambil dari 5 sampel setek. Homogenitas ragam diuji dengan Uji Bartlett, kemudian dilanjutkan dengan analisis sidik ragam. Untuk menguji beda nyata pengaruh antar perlakuan pada taraf nyata 5\% dilakukan uji Beda Nyata Jujur (BNJ).

\section{HASIL DAN PEMBAHASAN}

Berdasarkan hasil analisis sidik ragam dapat dikemukakan bahwa konsentrasi AIA 0 ppm, 100 ppm, 200 ppm, 300 ppm, dan 400 ppm berpengaruh nyata terhadap pertumbuhan setek cabang bambu kuning yaitu pada parameter persentase hidup, jumlah tunas, panjang tunas, diameter tunas, dan jumlah daun, sedangkan pada panjang akar tidak berpengaruh. Hasil rekapitulasi analisis ragam setiap variabel penelitian setek cabang bambu kuning disajikan pada Tabel 1.

Untuk mengetahui konsentrasi AIA yang berpengaruh paling baik terhadap variabel penelitian setek cabang bambu kuning dilakukan uji Beda Nyata Jujur (BNJ). Hasil rekapitulasi uji BNJ terhadap seluruh variabel penelitian setek cabang bambu kuning disajikan pada Tabel 2. Dapat dilihat pada Tabel 2. bahwa AIA berkonsentrasi 300 ppm dan 400 ppm menghasilkan persentase hidup yang lebih tinggi yaitu $88 \%$ dan $84 \%$, dibandingkan dengan setek cabang bambu kuning dengan konsentrasi 0 ppm, 100 ppm, dan 200 ppm.

AIA berkonsentrasi 300 ppm dan 400 ppm menghasilkan jumlah tunas yang lebih besar yaitu 4 buah dan 3 buah, dibandingkan dengan setek cabang bambu kuning dengan konsentrasi 0 ppm, 100 ppm, dan 200 ppm. AIA berkonsentrasi AIA 0 ppm dan 100 ppm menghasilkan panjang tunas yang paling panjang yaitu $25 \mathrm{~cm}$ dan $34 \mathrm{~cm}$, dibandingkan dengan setek cabang bambu kuning dengan konsentrasi 200 ppm, 300 ppm, dan 400 ppm.

AIA berkonsentrasi 0 ppm dan 100 ppm menghasilkan diameter tunas yang lebih baik yaitu $0,40 \mathrm{~cm}$ dan $0.43 \mathrm{~cm}$, dibandingkan dengan setek cabang bambu kuning dengan konsentrasi 200 ppm, 300 ppm, dan 400 ppm. AIA berkonsentrasi 0 ppm dan 100 ppm 
menghasilkan jumlah daun terbanyak yaitu 9 helai dan 8 helai, dibandingkan dengan setek cabang bambu kuning dengan konsentrasi 200 ppm, 300 ppm, dan 400 ppm. AIA berkonsentrasi 0 ppm, 100 ppm, 200 ppm, 300 ppm dan 400 ppm menghasilkan panjang akar yang sama baiknya.

Dari perhitungan persentase hidup diperoleh bahwa AIA berkonsentrasi $300 \mathrm{ppm}$ dan 400 ppm menghasilkan persentase hidup yang sangat tinggi yaitu $88 \%$ dan $84 \%$. Oleh karena itu, konsentrasi AIA ini sesuai untuk peningkatan persentase hidup bambu kuning. Lain halnya, pada konsentrasi 0 ppm, 100 ppm, dan 200 ppm mengalami penurunan persentase hidup, diduga penurunan persentase ini karena ada serangan hama yang merusak.

Tabel 1. Rekapitulasi analisis sidik ragam untuk seluruh variabel penelitian tentang pengaruh jumlah ruas cabang terhadap pertumbuhan setek bambu kuning pada umur 3 bulan.

\begin{tabular}{lcc}
\hline Variabel Penelitian & $\mathbf{F}_{\text {hitung }}$ & $\mathbf{F}_{(\mathbf{4} ; \mathbf{2 0})(\mathbf{0}, \mathbf{0 5})}$ \\
\hline Persentase hidup & $8,281^{*}$ & 2,886 \\
Jumlah tunas & $9,236^{*}$ & 2,886 \\
Panjang tunas & $3,389^{*}$ & 2,886 \\
Diameter tunas & $4,058^{*}$ & 2,886 \\
Jumlah daun & $4,398^{*}$ & 2,886 \\
Panjang akar & $0,096^{\mathrm{n}}$ & 2,886 \\
\hline
\end{tabular}

Keterangan : * = berbeda nyata pada taraf 5\%

tn $=$ tidak berbeda nyata pada taraf $5 \%$

Tabel 2. Rekapitulasi hasil uji BNJ untuk seluruh variabel penelitian tentang pengaruh jumlah ruas cabang terhadap pertumbuhan setek bambu kuning pada umur 3 bulan.

\begin{tabular}{|c|c|c|c|c|c|c|}
\hline \multirow{2}{*}{$\begin{array}{c}\text { Konsentrasi } \\
\text { AIA Yang } \\
\text { Diberikan Pada } \\
\text { Setek Cabang } \\
\text { Bambu Kuning }\end{array}$} & \multicolumn{6}{|c|}{ Variabel Penelitian Setek Cabang Bambu Kuning } \\
\hline & $\begin{array}{l}\text { Rata-rata } \\
\text { persentase } \\
\text { hidup (\%) }\end{array}$ & $\begin{array}{l}\text { Rata-rata } \\
\text { jumlah tunas } \\
\text { (cm) }\end{array}$ & $\begin{array}{l}\text { Rata-rata } \\
\text { panjang } \\
\text { tunas }(\mathrm{cm})\end{array}$ & $\begin{array}{c}\text { Rata-rata } \\
\text { diameter tunas } \\
(\mathrm{cm})\end{array}$ & $\begin{array}{l}\text { Rata- rata } \\
\text { jumlah } \\
\text { daun } \\
\text { (helai) }\end{array}$ & $\begin{array}{c}\text { Rata-rata } \\
\text { panjang } \\
\text { akar }(\mathrm{cm})\end{array}$ \\
\hline $0 \mathrm{ppm}$ & $48,000 \mathrm{bc}$ & $1,724 \mathrm{c}$ & $25,234 \mathrm{ab}$ & $0,408 \mathrm{a}$ & $8,780 \mathrm{a}$ & $6,600 \mathrm{a}$ \\
\hline $100 \mathrm{ppm}$ & $76,000 \mathrm{ab}$ & $2,442 b c$ & $34,032 \mathrm{a}$ & $0,432 \mathrm{a}$ & $8,030 \mathrm{a}$ & $6,000 \mathrm{a}$ \\
\hline $200 \mathrm{ppm}$ & $44,000 \mathrm{c}$ & $2,106 b c$ & $14,000 \mathrm{~b}$ & $0,278 \mathrm{bc}$ & $5,596 \mathrm{ab}$ & $2,600 \mathrm{a}$ \\
\hline 300 ppm & 88,000 a & $3,664 \mathrm{a}$ & $21,924 a b$ & $0,314 \mathrm{bc}$ & $6,594 \mathrm{ab}$ & $6,200 \mathrm{a}$ \\
\hline $400 \mathrm{ppm}$ & $84,000 \mathrm{a}$ & $2,926 \mathrm{a}$ & $13,424 \mathrm{~b}$ & $0,216 b$ & $3,904 \mathrm{~b}$ & $5,000 \mathrm{a}$ \\
\hline $\mathrm{BNJ}_{(0,05)}$ & 30,267 & 1,049 & 19,646 & 0,189 & 3,961 & $23,952^{\mathrm{tn}}$ \\
\hline
\end{tabular}

Keterangan : data pada setiap kolom yang diikuti oleh huruf yang sama tidak berbeda nyata pada taraf $5 \%$

Serangan hama yang merusak setek cabang bambu kuning ini berupa kumbang bubuk. Menurut Soedarmadi dan Karim (1959), kumbang bubuk menyerang tanaman bambu pada saat rebung muncul, karena pada saat itu bambu memiliki kandungan zat pati yang tinggi. Zat pati merupakan cadangan makanan utama pada tanaman bambu. Zat pati yang terdapat pada bambu ini merupakan sumber makanan organisme perusak.

Penelitian bambu kuning ini menggunakan jumlah ruas 2 buah. Penelitian Setiyawan (2000), banyaknya ruas bambu akan berpengaruh dalam perbanyakan tanamannya, karena 
dalam tiap ruas bambu terdapat cadangan makanan, sehingga semakin banyak ruas bambu yang dimiliki maka akan semakin banyak persediaan makanan yang dimiliki tanaman. Tanaman yang memiliki cadangan makanan cukup akan mampu bertahan hidup hingga pada kondisi kritis. Perbanyakan setek cabang bambu kuning dengan menggunakan jumlah ruas 2 buah memiliki cadangan makanan yang lebih rendah daripada jumlah ruas 3 buah.

Menurut Suradikusumah (1989), pemberian AIA berkonsentrasi tinggi akan mengakibatkan respon tanaman terhadap AIA berkurang sehingga menurunkan tingkat persentase hidup. Hal ini bisa terjadi, karena AIA yang diberikan dengan konsentrasi yang semakin besar akan mengurangi ketahanan dari sifat fisiologis tanaman. AIA pada tanaman secara umum mempengaruhi fisiologis tanaman seperti merangsang pembentukan tunas, daun, dan akar lateral, mempengaruhi pembengkokan batang, dan merangsang terjadinya proses diferensiasi tanaman.

Dari perhitungan jumlah tunas diperoleh bahwa AIA berkonsentrasi 300 ppm dan 400 ppm menghasilkan jumlah tunas yang lebih banyak yaitu 4 buah dan 3 buah. Oleh karena itu, konsentrasi AIA ini sesuai untuk peningkatan jumlah tunas. Menurut Sastrapradya dan Soenarko (1977), banyaknya jumlah tunas berkaitan dengan panjang tunas, dimana jenis yang mempunyai jumlah tunas yang banyak, panjang tunasnya cenderung pendek. Hal tersebut diduga karena semakin banyak kebutuhan akan bahan makanan maka akan terjadi persaingan. Jika jumlah tunas yang dimiliki dalam skala jumlah yang sedikit, maka persaingan untuk mendapatkan kebutuhan akan bahan makanan lebih sedikit, tetapi jika jumlah tunas yang dihasilkan dalam skala jumlah yang banyak maka persaingan antar tunas untuk mendapatkan bahan makanan akan menghambat perpanjangan tunas.

Dari perhitungan panjang tunas diperoleh bahwa AIA berkonsentrasi 0 ppm dan 100 ppm menghasilkan panjang tunas yang lebih baik yaitu $25 \mathrm{~cm}$ dan $34 \mathrm{~cm}$. Oleh karena itu, konsentrasi AIA ini sesuai untuk peningkatan panjang tunas. Dari perhitungan diameter tunas diperoleh bahwa AIA berkonsentrasi 0 ppm dan $100 \mathrm{ppm}$ menghasilkan diameter tunas yang lebih baik yaitu $0,40 \mathrm{~cm}$ dan $0,43 \mathrm{~cm}$. Oleh karena itu, konsentrasi AIA ini sesuai untuk peningkatan diameter tunas. Diameter tunas dipengaruhi oleh jumlah tunas, semakin sedikit jumlah tunas maka perkembangan tunas akan berkembang cepat dan semakin membesar ke samping, secara otomatis akan menghasilkan diameter tunas yang tinggi.

Dari perhitungan jumlah daun diperoleh bahwa AIA konsentrasi 0 ppm dan 100 ppm menghasilkan jumlah daun yang terbanyak yaitu 9 helai dan 8 helai daun. Oleh karena itu, konsentrasi AIA ini sesuai untuk peningkatan jumlah daun. Pengukuran panjang akar dalam penelitian dilakukan dengan tujuan untuk mengetahui seberapa besar efek AIA dalam proses pemanjangan akar bambu kuning, tetapi setelah diketahui hasil dari penelitian ini perlakuan AIA tidak berpengaruh nyata terhadap panjang akar. Diduga, panjang akar bambu sangat berpengaruh terhadap penyerapan air dan nutrisi dari dalam tanah, dimana semakin panjang akar tanaman maka akan semakin mudah tanaman untuk menyerap air dan nutrisi dari dalam tanah.

Berdasarkan hasil penelitian secara keseluruhan dapat diketahui bahwa, setek cabang bambu kuning dengan perlakuan AIA 100 ppm merupakan konsentrasi yang paling baik untuk persentase hidup dan pertumbuhan setek cabang bambu kuning. Perlakuan AIA 100 ppm dapat menghasilkan persentase hidup $76 \%$, jumlah tunas $2,442 \mathrm{~cm}$, panjang tunas $34,032 \mathrm{~cm}$, diameter tunas $0,432 \mathrm{~cm}$, jumlah daun 8 helai. Selain itu, faktor biaya juga merupakan salah satu pertimbangan dalam penelitian ini, dimana semakin banyak AIA yang digunakan maka biaya yang dibutuhkan akan semakin tinggi.

Suhu udara adalah salah satu faktor iklim yang berpengaruh terhadap laju pertumbuhan dan dengan demikian akan mempengaruhi laju penggunaan ion tanaman. Suhu mempengaruhi proses metabolisme tanaman. Pengaruh suhu terlihat pada laju perkembangan tanaman seperti pada perkecambahan, pembentukan daun (Rochiman dan Harjadi, 1973). 
Hasil pengukuran intensitas cahaya matahari, suhu, dan kelembapan udara pada pagi hari, siang hari, dan sore hari menunjukkan bahwa suhu udara di bawah naungan yaitu 31-35 ${ }^{\circ} \mathrm{C}$ dengan intensitas cahaya matahari 5.067-20.958,50 lux serta kelembapan udara yaitu 52-65\% (Tabel 3). Dengan keadaan lingkungan seperti ini rata-rata persentase hidup setek cabang bambu kuning cukup bagus karena pada tanah yang sesuai tanaman bambu akan tumbuh dengan baik karena kebutuhan makanan bagi tanaman tersebut akan terpenuhi (Berlian dan Rahayu, 1995).

Tabel 3. Rekapitulasi hasil pengukuran intensitas cahaya matahari, suhu, dan kelembapan udara.

\begin{tabular}{ccccc}
\hline No. & Pengukuran & $\begin{array}{c}\text { Intensitas cahaya matahari } \\
(\mathbf{l u x})\end{array}$ & $\begin{array}{c}\text { Suhu udara } \\
\left({ }^{\mathbf{o}} \mathbf{C}\right)\end{array}$ & $\begin{array}{c}\text { Kelembapan udara } \\
(\%)\end{array}$ \\
\hline 1. & Pagi hari & 5.067 & 31 & 65 \\
2. & Siang hari & $20.958,50$ & 35 & 52 \\
3. & Sore hari & 6.406 & 32,75 & 65 \\
\hline & Rata-rata & $10.810,5$ & 32,75 & 61 \\
\hline
\end{tabular}

\section{SIMPULAN}

Dari hasil penelitian dapat disimpulkan bahwa:

1. Pemberian AIA konsentrasi 100 ppm merupakan konsentrasi terbaik dalam perbanyakan bambu kuning (Bambusa vulgaris) pada penelitian ini serta mempertimbangkan faktor biaya dalam penggunaan AIA.

2. Pemberian AIA berpengaruh terhadap persentase hidup, jumlah tunas, panjang tunas,diameter tunas, dan panjang daun. Tetapi, tidak berpengaruh terhadap panjang akar.

\section{DAFTAR PUSTAKA}

Berlian, V. A. dan E. Rahayu. 1995. Jenis dan Prospek Bisnis Bambu. Buku. Penebar Swadaya. Jakarta. 89 p.

Departemen Kehutanan dan Perkebunan. 1999. Panduan Kehutanan Indonesia. Buku. Departemen Kehutanan dan Perkebunan. Jakarta. 23-27, 40-42 p.

Rochiman, K. dan S. S. Harjadi. 1973. Perkembangbiakan vegetatif. Bahan Bacaan Pengantar Agronomi. Fakultas Pertanian Institut Pertanian Bogor. Bogor. 12 p.

Sastrapradya dan S. Soenarko. 1977. Beberapa Jenis Bambu. Buku. Proyek Sumber Daya Ekonomi. Lembaga Biologi Nasional-LIPI. Bogor. 96 p.

Setiyawan, A. 2000. Pengaruh pemberian pupuk kandang ayam pada transplanting setek cabang 1 ruas dan 2 ruas bambu ampel hijau. Skripsi. Fakultas Pertanian Institut Pertanian Bogor. Bogor. 48 p.

Soedarmadi dan Karim. 1959. Pengawetan Bambu di Indonesia. Buku. Rimba Indonesia. 66$76 \mathrm{p}$.

Suradikusumah, E. 1989. Kimia Tumbuhan. Buku. Yayasan Penelitian Institut Pertanian Bogor. Bogor. 305 p.

Saefudin dan T. Rostiwati. 2009. Pemilihan bahan vegetatif untuk penyediaan bibit bambu. Jurnal Tekno Hutan Tanaman. 3(1):23-28. 